\title{
Development of Broad-Spectrum Natural Sunscreens using Combinations of five Plant Species
}

\author{
Laís Araújo', Sandya Curty' ${ }^{1}$, Alicia Moreira' ${ }^{1}$, Arthur Rossi ${ }^{1}$, Nádia Raposo ${ }^{2}$, Urias Vaz ${ }^{1,2}$, Hudson Polonini ${ }^{1,2, *}$ \\ 'Curso de Farmácia, Faculdade de Ciências Médicas e da Saúde de Juiz de Fora (Suprema), Juiz de Fora, BRAZIL. \\ ${ }^{2}$ Núcleo de Pesquisa e Inovação em Ciências da Saúde (NUPICS), Faculdade de Farmácia, Universidade Federal de Juiz de Fora, BRAZIL.
}

\begin{abstract}
Introduction: Cancer is a range of multifactorial diseases which have in common uncontrolled increase in the number of cells invading various tissues and organs. One of its leading etiological agents is sun exposure, and therefore the use of sunscreens plays an important role in cancer prevention. Objective: In this context, the aim of this study was to verify whether the selected naturally-derived raw materials (Oli-ola dry extract, Hibiscus dry extract, Raspberry ketones, Leucoanthocyanidins isolated from grapes and Resveratrol) present adequate photoprotective properties for the development of an innovative broad-spectrum sunscreen. Methods: The determination of sunscreen activity was made in vitro, and the following parameters were obtained: Sun Protection Factor (SPF), UVA Protection Factor (UVAPF), Critical Wavelength and Boots Star Rating. Results: Innovative products showed varied results (maximum SPF=46; maximum UVAPF=22), being that all of them showed to be promising for both parameters. However, the greatest protection was shown in the UVB region. Conclusion: Thus, the Oli-Ola, Hibiscus, Leucoanthocyanidins, Raspberry Ketones and Resveratrol species, grouped in a cosmetic base lotion, showed potential for the development of innovative sunscreen products. Additionally, the SPF should be confirmed in vivo.
\end{abstract}

Key words: Photoprotection, Natural sunscreens, Polyphenols, Flavonoids, Broad spectrum.

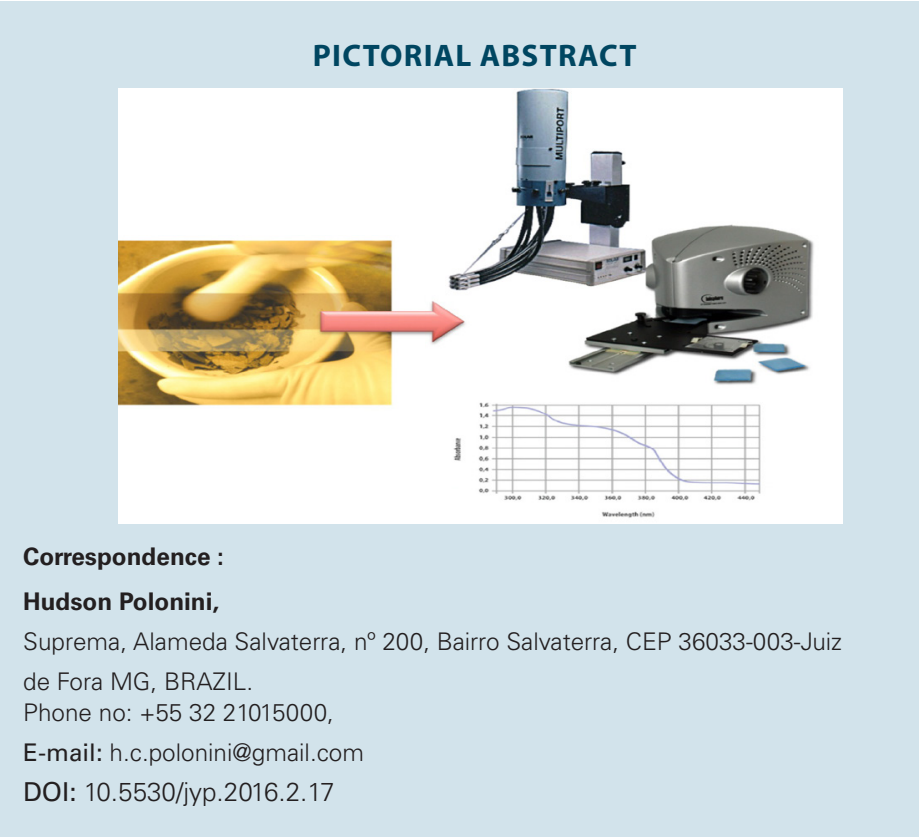

\section{INTRODUCTION}

Cancer is a range of multifactorial diseases having in common the uncontrolled increase of cells invading various tissues and organs. By dividing quickly and aggressively, these cells lead to the formation of neoplasms or tumors. ${ }^{1}$ Among the various types and subtypes of cancer, skin cancer is highlighted here, which is one of the most frequent public health problems in tropical countries; for example, it is responsible for $25 \%$ of all malignant tumors recorded in Brazil. Among the risk factors for this disease, genetic factors stand out, as well as family history and exposure to ultraviolet radiation (UV). In the latter case, it is known that exposure to sunlight is one of the main factors involved, which implies a greater incidence of skin cancer. ${ }^{2}$ Thus, there is an unquestionable need to use sunscreens.

According to Schalka et al. ${ }^{3}$ a sunscreen is defined as "a product for protection from sunlight, avoiding the potentially damaging effects of ultraviolet radiation, such as skin cancer." Thus, sunscreen products are applied to the skin of the human body; containing, in their formulation, components capable of absorbing, reflecting and/or diffracting sunlight, and thereby reducing its harmful effects. ${ }^{4}$ The aesthetic, fashion and cosmetics industries tend to influence the perception of society in terms of not considering the risks of sun exposure without proper protection. The population's awareness regarding the use of sunscreen in order to reduce the amount of absorbed ultraviolet rays and burns resulting from such exposure is of the utmost importance. ${ }^{5}$
Brazil has much of its territory located in critical areas of exposure to high UV index levels, one of the reasons why the use of sunscreens plays an important role in public health in this country. Perhaps for this reason, Brazil accounts for $20 \%$ of the sunscreens consumed worldwide, according to the Brazilian Market Potential Assessment by Category of the Brazilian Toiletries, Perfumery and Cosmetics Industry Association. In 2013, worldwide consumption in relation to the price which the consumer paid to acquire the product totaled US $\$ 8.2$ billion, of which $\$ 1.6$ billion came from Brazil. ${ }^{24}$

In light of the economic and public health impact that the use of sunscreen presents, the aim of this study was to verify whether the selected naturally-derived raw materials (Oli-ola dried extract, Hibiscus dried extract, Raspberry ketones, Leucoanthocyanidins isolated from grapes and Resveratrol) present adequate photoprotective properties for the development of a novel broad-spectrum sunscreen. These plant were chosen as they are currently highly used worldwide due to their known antioxidant properties.

\section{MATERIALS AND METHODS}

\section{Natural raw materials}

The raw materials of natural origin used, along with the labeled information, are as follows: Oli-Ola (Lot: 140381/Expires on: 04.28.2016/ Manufactured on: 04.28.2014/Supplier: Galena), Raspberry ketones (Lot: RKES98-130902/Expires on: 06.30.2016/Manufactured on: 09.30.2013/ 
Supplier: Gamma); Dry Hibiscus extract (Lot NPT 0614/494, Expires on: 06.30.2016/Manufactured on: 06.30.2014/Supplier: Florien); Isolated leucoanthocyanidins from grape (Lot CMPT22014221, Expires on: 02.28.2016 Manufactured On: 02.28.2014/Supplier: Gamma); Resveratrol (Lot: 100 504/Expires on: 05.10.2015/Manufactured On: 05/05/2010/ Supplier: SUNJJ) were all kindly donated by Singularis Pharmacy (São João Nepomuceno, Minas Gerais).

\section{Total phenolic content}

The determination of total phenolic content was performed by using Folin-Ciocalteu reagent in alkaline medium (saturated sodium carbonate). Gallic acid (Sigma-Aldrich, USA) was used as standard, and its ethanolic solutions $\left(25-700 \mu \mathrm{g} \mathrm{mL}^{-1}\right)$ were used to build-up a standard curve for determining the phenolic content of the extracts. The extracts were dissolved in ethanol $\left(10 \mathrm{mg} \mathrm{mL}^{-1}, \mathrm{n}=3\right)$, each one in isolation. Aliquots of the sample solutions $(50 \mu \mathrm{L})$ were mixed in test tubes with $250 \mu \mathrm{L}$ of Folin-Ciocalteu reagent, $500 \mu \mathrm{L}$ of $20 \%$ aqueous sodium carbonate and $4.2 \mathrm{~mL}$ of water. The test tubes were incubated protected from light at room temperature for 30 minutes, and then the absorbance of the solutions was read at $760 \mathrm{~nm}$ (UV Mini 1240, Shimadzu, Japan).

\section{Total flavonoid content}

Rutin (Sigma-Aldrich, USA) was used as standard, and its aqueous solutions (2-30 $\left.\mu \mathrm{g} \mathrm{mL}^{-1}\right)$ were used to build-up a standard curve for determining the flavonoid content of the extracts. The extracts were dissolved in ethanol $\left(10 \mathrm{mg} \mathrm{mL}^{-1}, \mathrm{n}=3\right)$, each one in isolation. In conical centrifuge tubes, $2.5 \mathrm{~mL}$ of the extract solutions were mixed with $1 \mathrm{~mL}$ of chloroform and $1.5 \mathrm{~mL}$ of water and then centrifuged for 3 minutes at $2.465 \times \mathrm{g}$ at $25^{\circ} \mathrm{C}(5810 \mathrm{R}$, Eppendorf, Germany). The microplates were prepared by adding the following solutions, in this order: $99 \mu \mathrm{L}$ of water; $25 \mu \mathrm{L}$ of $8 \%$ methanolic aluminum chloride hexahydrate solution; $100 \mathrm{~mL}$ of pyridine: methanol (2:8, v/v) solution; $6 \mu \mathrm{L}$ of glacial acetic acid; and $20 \mu \mathrm{L}$ of the supernatant of the centrifuged plant extract solution (or $20 \mu \mathrm{L}$ of each rutin solution). The plate was brought to stirring in a microplate shaker (SI-0400, Scientific Industries, USA) for 2 minutes and incubated in the dark for 15 minutes, always capped to prevent evaporation. After incubation, the absorbance was recorded in a microplate spectrophotometric microplate reader (SpectraCount Microplate Reader, Packard, USA) at a fixed wavelength of $405 \mathrm{~nm}$.

\section{Natural sunscreens}

Sun-care systems were developed by incorporating the dried extracts of the plant species through a cold process, with the composition described in Table 1.

\section{Photoprotection assay}

The extract was incorporated at $15 \%$ in a neutral cosmetic lotion. Two days later, it was accurately and quickly weighed $\left(1.3 \mathrm{mg} \mathrm{cm}^{-2}\right)$ in polymethylmethacrylate (PMMA) plates $(n=3)$. The plates were then protected from light exposure in a dark chamber at room temperature $\left(\approx 20^{\circ} \mathrm{C}\right)$ for 15 minutes, and afterwards they were measured from 290 to $450 \mathrm{~nm}$, at $1 \mathrm{~nm}$ intervals, at 9 different sites of each plate, using a transmittance analyzer (UV2000S, Labsphere, USA). For UVAPF, the plates were inserted into the UV irradiation source and then exposed to a calculated UV dose. After that, new transmission measurements of the sunscreen samples were conducted for acquisition of the second UV spectrum, and then the final UVAPF, the UVA/UVB Ratio and the Critical Wavelength $(\lambda c)$ were calculated. A detailed protocol and theoretical background can be found in Polonini and colleagues (2013). All results were expressed as a mean of 27 determinations ( 3 plates, 9 readings each, at different sites).

\section{RESULTS AND DISCUSSION}

The present study assessed the photoprotective activity of natural species of plants among the species selected. Oli-ola, whose scientific name is Olea europaea, is a typical plant of the Mediterranean region. ${ }^{7}$ Olea europaea contains a high rate of bioactive phenolic compounds, which are important due to their broad pharmacological activities; among which, the antioxidant, anti-inflammatory, anti-atherogenic, anti-cancer, antimicrobial and antiviral activities, as well as its hypoglycemic effects, stand out. ${ }^{8}$

Hibiscus sabdariffa, is a shrub which belongs to the Malvaceae family and is native from Asia and tropical Africa. It is widely cultivated in tropical regions due to its medicinal properties, as well its applications in textile industry and in cuisine. ${ }^{9}$ According to Ramos, ${ }^{10}$ it has a rich, mainly antioxidant and antibacterial, pharmacological effect. It contains phenolic compounds, (glycosylated anthocyanins stand out, as they are considered to be one of the main biologically active components), organic acids, steroids, terpenoids, polysaccharides and minerals.

The leucoanthocyanidins, also known as proanthocyanidins, are isolated from a species of grapes (Vitis vinifera). They are water soluble and their seeds are the part used. They belong to the natural polyphenol family, which, on their turn, belong to the bioflavonoid class, and are strong water-soluble antioxidants. Several studies demonstrate that the antioxidant strength of proanthocyanidins is several times higher than that of Vitamin E. ${ }^{11}$ Studies have shown that bioflavonoids bind specifically to components of the elastic fibers-collagen and elastin-in blood vessels. They increase the vessels' resistance to the degradative action of elastase and collagenase. Thus, the leucoanthocyanidins increase the tone and strength of the capillary walls. Their integrated action on dangerous free radical species may also be an important factor in capillary protection. ${ }^{11,12}$

Raspberry Ketones is the commercial name given to a natural phenolic compound responsible for the scent of red raspberries (Rubusidaeus) with beneficial properties for weight loss and body fat burn. They are extracted from the raspberry fruit itself, and are composed of $98 \%$ ketones. They act in conjunction with the lipase enzyme, which is responsible for the breakdown of lipid molecules so that they can be used as energy when needed. ${ }^{13}$ They are known to have antiatherosclerotic, antioxidant and thermogenic effects, being also used to fight obesity and in the treatment of metabolic syndrome and non-alcoholic fatty liver disease. ${ }^{13}$ Studies carried out by Japanese scientists ${ }^{13}$ demonstrated that the topical application of a $(0.01 \%)$ solution of Raspberry Ketones to the skin helps stimulate the IGF-1 growth factor in the dermis, thus resulting in an increase in skin elasticity.

Resveratrol is an herbal derivative belonging to the polyphenolic class of compounds. It is extracted from a plant whose scientific name is Polygonum cuspidatum. This substance is naturally synthesized in the plant under two isomeric forms: trans-resveratrol and cis-resveratrol; in the presence of light, the trans isomer is converted into cis, which is the most stable form. ${ }^{14}$ Studies indicate that this polyphenol was already known to eastern medicine, being used in the treatment of arteriosclerosis, inflammatory and allergic disorders. Its polyphenolic peculiarities make it possible to clarify its anti-platelet aggregation activity, as well as its antioxidant and triglyceride reduction properties. Still, resveratrol also has beneficial effects, such as the prevention of cancer, since it is capable of controlling the proliferation of cancer cells. ${ }^{15}$ However, the literature clarifies that resveratrol, associated with other natural plant species, has significant photoprotective activity when compared to other natural plant compounds tested alone. ${ }^{6}$

Since all of the species chosen have information described in the literature regarding the presence of flavonoids and phenolic compounds, 
Table 1: Planning matrix for the preparation of innovative sunscreens

\begin{tabular}{|c|c|c|c|c|c|}
\hline Sunscreen & OliOla(\%) & Hibiscus (\%) & Raspberryketones (\%) & Grapeleucoanthocyanidins (\%) & Resveratrol (\%) \\
\hline 01 & 0 & 0 & 0 & 0 & 20 \\
\hline 02 & 20 & 0 & 0 & 0 & 20 \\
\hline 03 & 0 & 20 & 0 & 0 & 20 \\
\hline 04 & 20 & 20 & 0 & 0 & 20 \\
\hline 05 & 0 & 0 & 20 & 0 & 20 \\
\hline 06 & 20 & 0 & 20 & 0 & 20 \\
\hline 07 & 0 & 20 & 20 & 0 & 20 \\
\hline 08 & 20 & 20 & 20 & 0 & 20 \\
\hline 09 & 0 & 0 & 0 & 20 & 20 \\
\hline 10 & 20 & 0 & 0 & 20 & 20 \\
\hline 11 & 0 & 20 & 0 & 20 & 20 \\
\hline 12 & 20 & 20 & 0 & 20 & 20 \\
\hline 13 & 0 & 0 & 20 & 20 & 20 \\
\hline 14 & 20 & 0 & 20 & 20 & 20 \\
\hline 15 & 0 & 20 & 20 & 20 & 20 \\
\hline 16 & 20 & 20 & 20 & 20 & 20 \\
\hline 17 & 10 & 10 & 10 & 10 & 10 \\
\hline
\end{tabular}

Table 2: Total phenolic constituents identified in the plant extracts

\begin{tabular}{ccc}
\hline Material & $\%(\mathrm{~m} / \mathrm{m})$ ofpolyphenols & mg polyphenols $/ \mathrm{g}$ of sample \\
\hline Hibiscus & 0.0 & 0.0 \\
Leucoanthocyanidins & 5.5 & 55.0 \\
Raspberry & 0.1 & 1.1 \\
Oliola & 6.6 & 65.6 \\
Resveratrol & 36.8 & 368.1 \\
\hline
\end{tabular}

Table 3: Flavonoid levels in plant extracts

\begin{tabular}{ccc}
\hline Material & $\%(\mathrm{~m} / \mathrm{m})$ offlavonoids & $\mathrm{mg}$ flavonoids $/ \mathrm{g}$ of sample \\
\hline Hibiscus & 0.0 & 0.0 \\
Leucoanthocyanidins & 15.2 & 151.6 \\
Raspberry & 17.1 & 171.0 \\
Oliola & 5.4 & 54.0 \\
Resveratrol & 9.9 & 98.5 \\
\hline
\end{tabular}

assays were performed in order to determine the actual amount of these compounds in the samples used in this study. The total levels of phenolic constituents present in each raw material can be found in (Table 2), being expressed as gallic acid, in percentages in relation to the weight. For the determination of the flavonoid content, the results are shown in Table 3.

Table 2 shows the total values of phenolic constituents for different raw plant materials, both in percentage and individually. A noteworthy discrepancy is shown between resveratrol outcomes when compared to others, since its concentration was clearly superior. Therefore, it is expected that the use of this raw material as a compound is more effective, strictly based on the values found for total phenolic constituents. The same cannot be said for the Hibiscus extract, since it showed no phenolic constituents in its composition, what is different from what was found by Ramos ${ }^{19}$-maybe due to seasonal or geographic reasons. The Leucoanthocyanidins and Oli-ola raw plant materials showed satisfactory results, taking into account the percentage of polyphenols presented.

Table 3 shows the values found for the flavonoid levels of the different types of plant extracts, expressed in percentage. It is found that the flavonoid content in raspberry and leucoanthocyanidin extracts is considerably larger than the other extracts. Resveratrol and Oli-ola extracts also showed satisfactory results, having flavonoid concentrations which guarantee the use of these extracts as photoprotective agents. Moreover, the flavonoid content was found to be absent when it comes to hibiscus extract, repeating the same results when compared to polyphenol levels, thus confirming the results regarding polyphenols. The significant difference between polyphenol and flavonoid levels for 


\begin{tabular}{|c|c|c|c|c|c|c|}
\hline Sunscreen & SPF & UVAPF & $\lambda_{c}$ & UVA/UVB Initial & UVA/UVB Final & Boots Star Rating \\
\hline 01 & $10 \pm 0.1$ & $5 \pm 0.4$ & 376 & 0.65 & 0.65 & $\star \star \star$ \\
\hline 02 & $38 \pm 0.3$ & $7 \pm 0.0$ & 373 & 0.59 & 0.59 & $\star \star \star$ \\
\hline 03 & $44 \pm 0.1$ & $12 \pm 0.1$ & 377 & 0.67 & 0.67 & $\star \star \star$ \\
\hline 04 & $21 \pm 1.0$ & $7 \pm 0.7$ & 377 & 0.64 & 0.65 & $\star \star \star$ \\
\hline 05 & $21 \pm 2.8$ & $8 \pm 0.8$ & 379 & 0.68 & 0.68 & $\star \star \star$ \\
\hline 06 & $25 \pm 7.2$ & $8 \pm 1.3$ & 378 & 0.65 & 0.65 & $\star \star \star$ \\
\hline 07 & $46 \pm 8.7$ & $22 \pm 8.3$ & 379 & 0.75 & 0.75 & $\star \star \star$ \\
\hline 08 & $45 \pm 37.5$ & $18 \pm 14.5$ & 381 & 0.72 & 0.72 & $\star \star \star$ \\
\hline 09 & $11 \pm 4.2$ & $6 \pm 0.2$ & 381 & 0.73 & 0.72 & $\star \star \star$ \\
\hline 10 & $24 \pm 5.9$ & $11 \pm 6.7$ & 383 & 0.76 & 0.76 & $\star \star \star$ \\
\hline 11 & $15 \pm 4.1$ & $6 \pm 0.1$ & 379 & 0.61 & 0.61 & $\star \star \star$ \\
\hline 12 & - & - & - & - & - & - \\
\hline 13 & $40 \pm 17.7$ & $10 \pm 4.1$ & 377 & 0.63 & 0.64 & $\star \star \star$ \\
\hline 14 & - & - & - & - & - & - \\
\hline 15 & - & - & - & - & - & - \\
\hline 16 & - & - & - & - & - & - \\
\hline 17 & $13 \pm 2.1$ & $5 \pm 0.3$ & 376 & 0.57 & 0.57 & $\star \star \star$ \\
\hline
\end{tabular}

other species indicates that the latter is probably not the main class of phenolic compounds present in the species. Resveratrol extract, for example, showed higher polyphenol content when compared to other extracts, but the amount of flavonoids was lower.

After this initial evaluation of the basic composition of plant materials, the photoprotective activity of the products handled with these materials was determined. Table 4 shows the values of the SPF, FPUVA; critical wavelengths; initial and final UVA/UVB relationship; as well as the Boots Star Rating.

After analyzing the data, it was found that all products presented SPF capable of being labeled, ranging from 10 to 46 . The activity of some products was not determined since they were too viscous to spread on the PMMA plates, thus preventing analysis. For those subject to analysis, the values exceeded the amounts normally found in the literature. ${ }^{16-19}$ According to Cabral et al, ${ }^{20}$ natural sunscreens presented considerably low absorption, so the use of plant extracts is recommended as adjuncts to the synthetic filters. Thus, the innovative product was surprising since it met the goal of developing a different naturally occurring product that provides skin protection, contributing to consumer acceptance.

Regarding UVAPF, the law stipulates that the value should correspond to at least $1 / 3$ of the SPF value stated on the label (FDA) ${ }^{21,22}$ As shown in Table 4, all of the species analyzed are within the established parameters. Critical Wavelength is another parameter settled to measure the UVA protection, since it defines the spectrum of protection (sunscreens with $\lambda c$ values near $400 \mathrm{~nm}$ are considered broad spectrum). The US Food and Drug Administration (FDA) (2011) uses this parameter to determine whether a product is a broad spectrum sunscreen or not. It considers the broad spectrum test as a pass/fail test based on the critical wavelength value of $370 \mathrm{~nm}$. In this study, all $\lambda \mathrm{c}$ were greater than $370 \mathrm{~nm}$ (Table 4), that is, all of the products can be considered of broad spectrum.

Finally, we have determined the UVA/UVB Ratio, which provides a good idea of which UV region is better blocked by the substances. The UVA/ UVB ratio can also be used to provide the so-called Boots Star Rating (2008), which classifies products into categories from 0 to 5 stars. Such classification should be done according to initial and post exposure to UVA/UVB Ratios. The Boots Star Rating is important to determine the stability of the photoprotection values generated, since the components of the sunscreens may degrade. According to the Boots Star data presented in Table 4, the 13 formulations tested were rated with 3 stars.

\section{CONCLUSION}

The species Oli-ola, Hibiscus, Leucoanthocyanidin, Raspberry Ketones and Resveratrol, grouped into a cosmetic base lotion, resulted in many possibilities of innovative sunscreen products with SPF reaching up to 46 . These data are promising, and as soon as the SPF is confirmed in vivo and its safety profile is determined, such products may be placed on the market.

\section{ACKNOWLEDGEMENTS}

The authors are truly grateful to Maria Arabela Galil Silva (Singularis Farmácia de Manipulação) for the kind donation of materials.

\section{CONFLICT OF INTEREST}

The authors declare that they have no conflict of interest. 


\section{ABBREVIATIONS USED}

None.

\section{ABOUT AUTHORS}

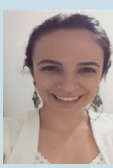

Lais Rodrigues Araújo: Is a Pharmacy student at the School of Medical Sciences and Health of Juiz de Fora - Suprema (FCMS/JF). She has the following additional training: Clinical Interpretation of Laboratory Results Extension Course (FCMS/JF-Suprema), Clinical Pharmacy Extension Course (FCMS/JF) and Oncology Pharmacy Extension Course (Neoclínica). She joined the Extension Project called "Cuidar para Sorrir" (Provide Care and Gain a Smile) in the Intensive Care Unit at Therezinha of Jesus Hospital (HTJ). Her research interests are in cosmetics, with an emphasis on sunscreens.

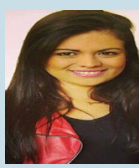

Sandya Curty Rodrigues: Is a Pharmacy student at the School of Medical Sciences and Health of Juiz de Fora-Suprema (FCMS/JF). A trainee in the Regional Health Superintendence-RHS/state of Minas Gerais, at the Sanitary Surveillance center and at Mount Sinai Hospital. Member of the Dr. Djalma Rabelo Ricardo Academic Board of Pharmacy. She was a monitor in the disciplines of Clinical Cytology, Biochemistry, Microbiology and Immunology. She has participated in Clinical Pharmacy and Oncology Pharmacy Extension Courses. She has participated in the Extension Project called "Cuidar para Sorrir" (Provide Care and Gain a Smile) in the Intensive Care Unit at Therezinha of Jesus Hospital (HTJ), with focus on the prevention of pneumonia associated with mechanical ventilation. She has Clinical Analysis Laboratory experience. She conducts studies in cosmetology, with focus on the development of innovative natural sunscreens.

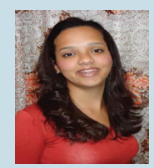

Alicia Moreira: Is a Pharmacy student at the School of Medical Sciences and Health of Juiz de Fora-Suprema (FCMS/JF). She has worked in a compounding pharmacy, focusing on solid cosmetics and medicines. Graduated as a pharmacy technician, she is experienced in pharmaceutical quality control. Natural plant sunscreen is her main line of research.

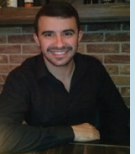

Arthur Fonseca Rossi: Is a Pharmacy student at the School of Medical Sciences and Health of Juiz de For a-Suprema (FCMS/JF). He has worked as a trainee in different fields of the pharmaceutical area, such as Allopathic Pharmacy, Compounding Pharmacy, Clinical Analysis Laboratory, as well as a trainee at the Regional Superintendence of Juiz de Fora, in the Health Surveillance sector. He has recently participated in an exchange program at the University of Florence, Italy, where he had the opportunity to improve his studies in the pharmaceutical area, also taking part in an internship program in a Pharmacology Laboratory. Currently, he conducts studies for the development of new sunscreens.

\section{REFERENCES}

1. Araújo TS, Souza SO. Protetores solares e os efeitos da radiação ultravioleta. Scientia Plena. 2008;4:1-7.

2. Instituto Nacional do Câncer. Câncer de Pele. Available from: http://www.inca. gov.br/estimativa/2014/index.asp?|D=2 Accessed to July 28, 2015.

3. Schalka S, Reis VMS. Fator de proteção Solar: Significado e Controvérsias. An Bras. Dermatol. 2011;86(3):507-15.

4. Costa FB, Weber MB. Avaliação dos hábitos de exposição ao sol e de fotoproteção dos universitários da Região Metropolitana de Porto Alegre, RS. An Bras. Dermatol. 2004;79(2):149-55.

5. Silva CA, Pereira DC, Marques ED, Rahal ICKA, Falconi K, Favaretto L. A ciência Cosmética como instrumento da Saúde Pública: uso correto de fotoprotetores. Rev Bras Farm. 2009;90(2):159-65

6. Polonini HC, Lima LL, Gonçalves KM, Carmo AMR, Silva AD, Raposo MRB. Protoprotective Activity of resveratrol analogues. Bioorganic e Medicinal Chemistry. 2013;21:964-8.

7. Kim MS, Koppula S, Jung SH, Kim JY, Lee HR, Lee SR, et al. Olea europaea linn (oleaceae) fruit pulp extract exhibits potent antioxidant activity and attenuates neuroinflammatory responses in lipopolysaccharide-stimulated microglial cells. Trop J Pharm Res. 2013;12(3):357-62.

8. Sahranavard S, Kamalinejad M, Faizi M. Evaluation of Anti-Inflammatory and Anti-Nociceptive Effects of Defatted Fruit Extract of Olea europaea. Iranian. Journal of Pharmaceutical Research. 2014;119-23.

9. Mahadevan N, Shivali KP, Kamboj P. Hisiscus sabdariffa Linn. Natural Product Radiance. 2009;8(1):77-83

10. Ramos DD, Vieira MC, Formagio ASN, Cardoso CAL, Ramos DD, Carnavali TO. Atividade antioxidante de Hibiscus sabdariffa L. em função do espaçamento entre plantas e da adubação orgânica. Ciência Rural. 2011:41(8):1331-6.

11. Abe LT, Mota RV, Lajolo FM, Genovese MI. Compostos fenólicos e capacidade antioxidante de cultivares de uvas Vitis labrusca L. e Vitis vinifera L. Ciênc. Tecnol. Aliment. 2007;27:394-400.
12. Arce ER, Soto MAC, Gattuso M, Legorreta XL, Larza EMG, Garcia EC. Bases farmacológicas y clinicas Del extracto de Vitis vinifera em patologias asociadas al estrés oxidativo. Revista de Fitoterapia. 2003;3(2):135-44.

13. Okajima HK, Narimatsu N, Kurihara H, Nakagata N. Effect of topical application of raspberry ketone on dermal production of insulin-like growth factor-l in mice and on hair growth and skin elasticity in humans. Growth Hormone and IGF Research. 2008;18(4):335-44.

14. Sautter CK, Denardin S, Alves AO, Mallmann CA, Penna NG, Hecktheuer LH Determinação de Resveratrol em Sucos de Uva no Brasil. Ciên Tecnol Aliment. 2005;25(3):437-42.

15. Moreno CS. Estudo do Efeito Radioprotetor do Resveratrol. 2009.

16. Ferrari M, Oliveira MSC, Nakano AK, Rocha FPA. Determinação do fator de proteção solar (SPF) in vitro e in vivo de emulsões com óleo de andiroba (Carapa guianensis). Rev Bras Farmacogn. 2007;17(4):626-30.

17. Pianovski AR, Vilela AFG, Lima CG, Silva KK, Carvalho VFM, Musis CR, et al. Desenvolvimento e avaliação da estabilidade de emulsões múltiplas O/A/O com óleo de pequi (Caryocar brasiliense). Rev Bras Farm. 2008;89(2):155-9.

18. Violante IMP, Souza IM, Venturini CL, Ramalho AFS, Santos RAN, Ferrari M. Avaliação in vitro da atividade fotoprotetora de extratos vegetais do cerrado de Mato Grosso. Rev Bras Farmacogn. 2009;19(2A):452-7.

19. Ramos MFS, Santos EP, Dellamora-Ortiz GM. Avaliação da Atividade Antisolar e Estudos Preliminares de Fotodegradação da Própolis. Revista Fitos. 2010;5(3):73-84

20. Cabral LDS, Pereira SO, Partata AK. Filtros solares e fotoprotetores mais utilizados nas formulações no brasil. Revista Científica do ITPAC. 2011;4(3):1-10.

21. Food and Drug Administration CP, 310 and 352. Sunscreen Drug Products for Over the Counter Human Use; Final Rules and Proposed Rules. Silver Spring 2011.

22. RESOLUÇÃO-RDC N ${ }^{\circ} 30 \mathrm{DE} 1^{\circ} \mathrm{DE}$ JUNHO DE 2012. Aprova o Regulamento Técnico Mercosul sobre Protetores em Cosméticos e dá outras providências. 